\title{
Personal values and South African financial services brand preference
}

\author{
Steven M. Burgess* \\ School of Economic and Business Studies, University of the Witwatersrand, Private Bag 3, P.O. Wits 2050 \\ Republic of South Africa \\ Roger D. Blackwell \\ College of Business, Consumer Research, The Ohio State University, United States of America
}

Received December 1991, accepted September 1993

\begin{abstract}
Personal values have become an important concept in consumer research. The authors test the value importance-brand preference link, compare brand preference value correlates with the universal content and structure recently proposed by Schwartz, and propose a method of market segmentation based on traditional segmentation criteria and values. The results suggest individual values should remain the focus of consumer research concerning values, that inconsistent patterns of significant values emerge compared to Schwartz's theoretical structure and that values are more important than age, education and household income to an efficient segmentation solution. However, race was the most important segmentation variable and marketers should not disregard it.
\end{abstract}

\begin{abstract}
Persoonlike waardes het 'n belangrike begrip geword in verbruikersnavorsing. Die outeurs toets die verband tussen waarde-belangrikheid en handelsmerkvoorkeur, vergelyk handelsmerkvoorkeur waardekorrelate met die universele inhoud en struktuur soos onlangs voorgestel deur Schwartz, en hulle stel 'n metode vir marksegmentasie voor, gebaseer op tradisionele segmentasie kriteria en waardes. Die resultate suggereer dat individuele waardes die fokus moet bly van verbruikersnavorsing oor waardes, dat ontoepaslike patrone van betekenisvolle waardes na vore tree vergeleke met Schwartz se teoretiese struktuur en dat waardes belangriker is as ouderdom, opvoeding en huishoudelike inkomste vir 'n doeltreffende oplossing van segmentasie. Ras was egter die belangrikste segmentasieveranderlike en bemarkers moet dit nie buite rekening laat nie.
\end{abstract}

*To whom correspondence should be addressed.

\section{Background}

Personal values entered the consumer research mainstream during the past decade. Psychology and Marketing (1985), Journal of Advertising Research (1988) and Journal of Business Research (1990) devoted special issues to the concept, a new comprehensive theory of consumer behaviour based on values attracted widespread attention (Sheth, Newman \& Gross, 1991), and the American Psychological Association's Society for Consumer Psychology devoted the entire 1993 Annual Conference to values research. In local and international applied research, values became an integral component of most commercial segmentation schemes. An historical perspective highlights the significance of these devclopments (see Burgess, 1992; and Clawson \& Vincent, 1978 for historical reviews).

Engel, Kollat \& Blackwell (1968) first proposed the central role of values in consumer decision-making more than 25 years ago. Kassarjian (1965) and Cohen (1968) also recognized value influence on limited aspects of consumer behaviour. Eager to progress quickly, early consumer researchers borrowed eclectically from other behavioural sciences. Unfortunately, the bchavioural sciences literature concerning values was 'awash with unrelated concepts and their attendant instrumentation' (Bond, 1991: 137) and progress was slow.

During the seventies, Rokeach $(1968,1973,1979)$ proposed a new values theory that attracted significant multidisciplinary interest in the behavioural sciences (see Burgess, 1992: 48-55). The theory suggested that values are hierarchically-ordered, transituational beliefs about desirable end-states and modes of conduct possessed in differing degrees of intensity by all people. Rokeach's major innovation was to clearly differentiate beliefs, attitudes and values (Braithwaite \& Law, 1985: 250).

At about the same time, the consumer research literature voiced growing disenchantment with personality traits (compare, Britt, 1966: 134-150; Engel Blackwell \& Kollah, 1978: 198-205; Engel, Blackwell \& Miniard, 1993: 358-359; Kassarjian, 1971; Kassarjian \& Sheffet, 1991). Rokeach's (1973: 21) conceptualization of people as 'a system of values' rather than as 'a cluster of fixed traits' appealed to critics of the fixed nature of trait (i.e., Kahle, Beatty \& Homer, 1986) because it made it possible to conceive of individual change as a result of social change. Further, Rokeach (1973: 116-117) demonstrated links between value importance and consumer preferences (which he termed inconsequential attitudes). His theory soon became the seminal influence on consumer research concerning values and researchers began to report impressive results linking values to many aspects of consumer behaviour (see Burgess, 1992 , especially pp.58-65).

The value importance-behaviour link is now widely accepted and the focus of values research has shifted to content and structure. Schwartz (Schwartz, 1992; Schwartz \& Bilsky, 1987; 1990) recently proposed a new theory concerning the universal content and structure of values and a value survey for measuring them. He tested value structure by analyzing the Pearson intercorrelations of value ratings using Smallest Space Analysis (SSA) and reported empirical support from 35 countries for many elements of the theory. SSA is a non-metric multidimensional scaling technique originated by Gutuman and Lingoes (Gutuman, 1968). See Canter (1985) and Davison (1983) for more complete discussions regarding the rationale and procedures for using SSA. Schwartz (1992) and Schwartz \& Bilsky $(1987 ; 1990)$ 
has demonstrated the usefulness of SSA in values research.

Schwartz' theory proposes that values are transituational goals that serve the interest of individuals and/or collectivities and express one of ten universal motivations. Multiple value measurement methods and very diverse samples are crucial for assessing the degree of universality of such a proposition (Poortinga \& Malpass, 1990; Triandis, 1990). Thus, Burgess, Schwartz \& Blackwell (1993) reported results using both the new Schwanz Value Survey (SVS) (Schwartz, 1992) and the Rokeach Value Survey (RVS) (Rokeach, 1973) in two separate studies. The current research concerns the values and brand preferences of the 1364 respondents who completed the RVS-data originally collected in 1989 as part of a comprehensive doctoral research programme but not previously analyzed as presented here.

Cross-cultural research using standardized value scales requires careful consideration of two possible sources of bias: (1) inconsistent meaning of value stimuli; and (2) lack of understanding of the value stimuli due to poor literacy skills or linguistic reasons (see Howard, 1977; and Munson \& McQuarrie, 1988). Rokeach (1973: 49-51) addressed the difficulty of assessing value meaning from behaviouristic, connative, semantic and psychological significance viewpoints. He concluded that relative value importance is an important way to understand meaning differences. More recently, Schwartz \& Sagiv (1992) noted that the meaning of an individual value is reflected in the pattern of its intercorrelation with other values.

The instrument was used in interviews with a small diverse sample of respondents. The pretest of the RVS Form $D$ suggested that the instructions and value statements had equivalent meanings across the South African subsamples, with three exceptions. (1) Equality implied different consequences for members of different ethnic groups. (2) Salvation was probably meaningless to believers in the Nguni concept of an afterlife, strongly linked to this world (Berglund, 1976; Hammond-Tooke, 1989). (3) Fundamentalist Christians and Muslims sometimes found the linking of sexual and spiritual intimacy in the defining phrase of mature love problematic. However, these small differences do not seem to have a significant negative influence on the results.

If respondents were ranking values randomly because of low literacy skills, language comprehension or some other reason, inter-respondent reliability would be low and Kendall's Coefficient of Concordance $w$, a measure of interrespondent reliability that can be tested for significance using $X^{2}$ (Siegal \& Castellan, 1988: 262-272), would not be significant. Testing for non-homogeneous respondent response indicates the probability of $\mathrm{X}^{2} \leq .00001$ at every level of geographic, age, linguistic, racial, working status, and occupational classifications with more than five respondents. Of course, concordance does not prove meaning equivalency: Respondents with similar characteristics could agree on similar value meanings that may or may not be the same as respondents with other characteristics. Similarly, discordant respondents might share similar meaning but disagree about the importance of values. However, results such as these indicate an exceptional degree of concordance unlikely to exist unless respondents shared meaning.
There is further evidence of shared meaning. Burgess, Schwartz \& Blackwell (1993) reported extensively about the values data used in the current research. In summary, they reported that the four-dimensional SSA produced coefficients of alienation less than .015 for the total sample and the four traditional racial subsamples, suggesting an excellent representation of the value intercorrelations. In all cases, the SSA produced value structures that differed significantly from a random arrangement of the values toward Schwart' hypothesized value structure.

Compared in Table 1 are the interests served by South African values and their motivational domains to Schwartz' theory. A minimum of 21 of the 36 values emerged in the hypothesized motivational domain (the average was 23.4). An average of 33.4 values emerged in a region serving the hypothesized interest. Only 2.6 values reversed interests on average. Thus, the findings indicated support for Schwart' theory and shared value meanings across groups.

\section{Personal values and market segmentation}

Historical reviews suggest market segmentation has been the most common use of values in consumer research. Values provide an improved method of segmentation in which consumption-related variables are linked to core consumer values (Engel, Blackwell \& Miniard, 1993: 364-366). It is hard to think of a contemporary South African marketing issue that has attracted more attention or more sharply divided opinion than racial market segmentation. The distinctive differences in literacy, numeracy, education, culture, age, occupation and economic resources that correlate with race make a strong case for racial segmentation. However, non-racial conceptualizations of South African consumers, such as Sinclair's (1985: 64-66) marketing bands concept. often suggest marketing strategy should be directed toward customer values, attitudes and beliefs rather than toward fixed individual characteristics assumed to be shared by perceived ethnic groups undergoing rapid social change.

Values have been used for segmentation in two main ways. Commercial segmentation schemes, such as the wellknown VALS scheme, use values as a major component to produce standard segments for use with any product. These commercial schemes have declined in popularity and the international trend is toward research with more immediate strategic relevance in recent years (Business Week, 1991). Alternatively, value surveys such as the RVS can be included in a standard questionnaire. It appears that the value importance differences measured by value surveys correlate better with consumption behaviour than commercial value and lifestyle segmentation schemes such as VALS (Kahle, Beatty \& Homer, 1988; Novak \& MacEvoy, 1990).

The current research is intended to make three original contributions to the literature: (1) to test the value importance-brand preference link for South African financial service brands; (2) to compare brand preference value correlates with the universal structure and content proposed by Schwartz; and (3) to propose a method of market segmentation based on values and traditional segmentation criteria, such as age, education, household income and race. 
Table 1 Predicted and observed location of Rokeach values: Interests served and motivational types

\begin{tabular}{|c|c|c|c|c|c|c|c|}
\hline $\begin{array}{l}\text { Interest } \\
\text { served }\end{array}$ & $\begin{array}{l}\text { Motivational } \\
\text { type }\end{array}$ & $\begin{array}{l}\text { Hypothetical } \\
\text { content }\end{array}$ & & Asians & $\begin{array}{l}\text { Actual content } \\
\text { Blacks }\end{array}$ & Coloureds & Whites \\
\hline Mixed & Universalism & $\begin{array}{l}\text { A world of beauty } \\
\text { A world at peace } \\
\text { Broadminded } \\
\text { Courageous } \\
\text { Equality } \\
\text { Inner harmony } \\
\text { Mature love } \\
\text { Self-respect } \\
\text { Wisdom }\end{array}$ & $\begin{array}{l}\text { Inner harmony } \\
\text { Mature love } \\
\text { Responsible* } \\
\text { Self-controlled* } \\
\text { Self-respect } \\
\text { Wisdom }\end{array}$ & $\begin{array}{l}\text { A world of benuty } \\
\text { A world at peace } \\
\text { Broadminded } \\
\text { Capable* } \\
\text { Couragoous } \\
\text { Equality } \\
\text { Freedom* } \\
\text { Matyre love }\end{array}$ & $\begin{array}{l}\text { Courngeous } \\
\text { Equality } \\
\text { Independent* } \\
\text { Responsible* } \\
\text { Self-respect } \\
\text { Social recognition* } \\
\text { Wisdom }\end{array}$ & $\begin{array}{l}\text { Broedminded } \\
\text { Happiness* } \\
\text { Inner harmony } \\
\text { Mature love } \\
\text { Responsible* } \\
\text { Self-respect } \\
\text { True friendship* } \\
\text { Wisdom }\end{array}$ & $\begin{array}{l}\text { A sense of } \\
\text { accomplishment* } \\
\text { Happiness" } \\
\text { Inner harmony } \\
\text { Meure love } \\
\text { Responsible* } \\
\text { Self-controlled* } \\
\text { Self-respeca } \\
\text { Wiedom }\end{array}$ \\
\hline Individual & Achievement & $\begin{array}{l}\text { Ambitious } \\
\text { A sense of } \\
\text { accomplishment } \\
\text { Capable } \\
\text { Social recognition }\end{array}$ & $\begin{array}{l}\text { A sense of } \\
\text { accomplishment } \\
\text { Capable } \\
\text { Courageous* } \\
\text { Equality* } \\
\text { Freedom } \\
\text { Imaginative } \\
\text { Independent } \\
\text { Intellectual } \\
\text { Logical }\end{array}$ & $\begin{array}{l}\text { Independent } \\
\text { Inner harmony* } \\
\text { Intellectual } \\
\text { Logical } \\
\text { Responsible** } \\
\text { Setf-controlled** } \\
\text { Self-respect* } \\
\text { Wisdom* }\end{array}$ & $\begin{array}{l}\text { A comfortable life } \\
\text { A world at peace* } \\
\text { A world of beaury* } \\
\text { Cheerful } \\
\text { Clean** } \\
\text { Mature love* } \\
\text { Pleasure } \\
\text { Broadminded* } \\
\text { Freedom } \\
\text { Imaginative } \\
\text { Inner harmony* } \\
\text { Intelloctual } \\
\text { Logical } \\
\text { National security** }\end{array}$ & $\begin{array}{l}\text { A sense of } \\
\text { accomplishment } \\
\text { Capable } \\
\text { Independent } \\
\text { Intellectual } \\
\text { Logical } \\
\text { Self-controlled** }\end{array}$ & $\begin{array}{l}\text { Ambitious } \\
\text { Broadmindat* } \\
\text { Courageous } \\
\text { Equality* } \\
\text { Independent } \\
\text { Social recognition } \\
\text { A comforrable life } \\
\text { Plessure }\end{array}$ \\
\hline Collective & Benevolence & $\begin{array}{l}\text { Forgiving } \\
\text { Helpful } \\
\text { Honest } \\
\text { Loving } \\
\text { Responsible } \\
\text { Salvation } \\
\text { True friendship }\end{array}$ & $\begin{array}{l}\text { A world at peace* } \\
\text { Cheerful** } \\
\text { Forgiving } \\
\text { Happiness** } \\
\text { Helpful } \\
\text { Honest } \\
\text { Loving } \\
\text { Salvation } \\
\text { True friendship } \\
\text { Obedient } \\
\text { Polite }\end{array}$ & $\begin{array}{l}\text { Family socurity } \\
\text { National security } \\
\text { Salvation } \\
\text { Social recognition** } \\
\text { True friendship }\end{array}$ & $\begin{array}{l}\text { Family security } \\
\text { Forgiving } \\
\text { Happiness** } \\
\text { Helpful } \\
\text { Honest } \\
\text { Loving } \\
\text { Salvation } \\
\text { True friendship }\end{array}$ & $\begin{array}{l}\text { Clean } \\
\text { Obedient } \\
\text { Polite } \\
\text { A world at peace* } \\
\text { A world of beaury* } \\
\text { Courageous* } \\
\text { Equality* } \\
\text { Family security } \\
\text { Family security } \\
\text { National security } \\
\text { Social recognition ** }\end{array}$ & $\begin{array}{l}\text { Cheerful** } \\
\text { Helpful } \\
\text { Obedient } \\
\text { Polite } \\
\text { A world at peace* } \\
\text { A world of beaury* } \\
\text { Clean } \\
\text { National security }\end{array}$ \\
\hline
\end{tabular}

Source: Burgess, Schwartz \& Blackwell (1993). Note: Sample sizes: Asians 183, Blacks 387, Coloureds 191, Whites 603. Total sample 1365. Values in inalics are misplaced in a motivational type serving the same interes. Values marked * are mispleced between mixed and other interests. Values marked ** have reversed placement between collective and individual regions. Combined value types were present: Benevolence, conformity and security values (cotal semple), benevoleace and conformity values (Blacks and Asians) and achievement and hedonism values (Whites). 


\section{Method}

Sample

The same race interviewers from a leading market research company administered the Afrikaans and English survey to an area- and race-stratified probability sample consisting of 200 Asians, 402 Blacks, 200 Coloureds and 603 Whites over the age of 18 living in major metropolitan areas (over 200.000 people). Forty-one respondents did not complete all sections of the instrument, so the final sample consisted of 1364 respondents (183 Asians, 387 Blacks, 191 Coloureds and 603 Whites). Interviewers reported that less than $2 \%$ of respondents were unable to complete the survey due to language comprehension problems. South Africa's rapid urbanization makes urban sample comparisons difficult. However, drawing on AMPS 87/8 (South African Advertising Research Foundation, 1989), Mostert \& Lötter (1991) and Hofmeyer \& Mostert (1989), the sample is reasonably representative of the sampling frame.

\section{Instrument and procedure}

The pretesting with diverse respondents preceding the study indicated a need for an expanded instruction set. The first part of the instrument followed Rokeach's (1973) RVS Form D methodology in all respects. However, the revised instruction set urged respondents to 'work slowly and think carefully', 'change your mind as often as you like', 'show how you truly feel' and assured them there were 'no right or wrong answers'. Questionnaire design and translation procedure followed Berry (1969) and Brislin, Lonner \& Thorndike (1973).

Following Feather (1984) and Rosenberg (1956), the values were presented on cards to make it easier for the respondent to change their mind and rearrange them. Shuffling the cards upon presentation to the respondent eliminated order effects.

The second part of the questionnaire introduced a comprehensive list of well-known banks on a display card and said, 'Here are the names of some well-known banks. Could you please tell me with which bank would you be most likely to open a new current account, cheque account or savings account?' Respondents were allowed only one choice. The building socicties question used the same wording and the brands were shown on a separate card. In both product categories, the brands tested represented over $90 \%$ of market share according to industry data. Interviewers collected demographic information at the end of the interview.

\section{Results}

\section{Value importance and brand preference}

Numerous studies have advanced a theoretical rationale linking values to many aspects of consumer behaviour (see Gutman, 1982; Lessig, 1975; Sheth, Newman \& Gross, 1991; and Vinson, Scou \& Lamonh, 1977). The current research pursues three hypotheses concerning the nature and extent of the value importance-brand preference link.
Hypothesis 1: Differences in the relative importance of personal values correlate with financial services brand preference.

The first hypothesis concerns the relative importance of individual values and brand preference. This link has been established in numerous international studies (see Burgess, 1992). Similar to Rokeach (1973: 56), preliminary data analysis indicated non-normal distributions and variance heterogeniety characterized the ranked data - suggesting nonparametric statiștical analysis - and the Kruskal-Wallis One-Way Analysis of Variance was selected as best suited to the analysis (Feir-Walsh \& Toothaker, 1974; Siegel \& Castellan, 1988: 200-215). The use of nonparametric statistics had an important secondary advantage: the possibility of instrumentation bias effects was reduced (Burnett \& Bar, 1977). To account for inflated $\alpha$ levels resulting from the repeated measures design (LaTour \& Miniard, 1983), results were considered significant when $\alpha \leq .0028$ per comparison. Admittedly conservative, this Bonferroni correction estimates a family-wise error rate of $\alpha \leq .05$ (see Bird, 1985; Fisher \& McDonald, 1978; Gaito, 1978; Keppel, 1982; and Roger, 1973).

The results do not contradict the hypothesis. Differences in the relative importance of six values correlated significantly with bank preference: an exciting life, equality, happiness, national security, salvation and self-control. Differences in the relative importance of a sense of accomplishmen, equality, pleasure, wisdom and logic correlate significantly with building society preference. Only equality, the value most differently ranked by the four race groups ( $\mathrm{p} \leq .00001)$, is related significantly to preference in both categories.

Hypothesis 2: South Africans who prefer different financial institution brands have different value systems.

The second hypothesis concems value system differences and brand preference. Are the significant differences in relative value importance identified above enough to conclude consumers who prefer different brands have different value systems? This hypothesis was tested by isolating the group level median terminal and instrumental value rankings of respondents preferring different brands and testing pairwise comparisons of the 18 terminal values and the 18 instrumental values for significance, using the Spearman Rank Order Correlation Coefficient $r_{s}$. The relationship was insignificant at $\alpha=.05$ for each of the 60 possible comparisons (two lists of 18 values $\times 15$ comparisons of six brands in each category). Thus, individual values appear to be more important than value systems in determining financial services brand preference.

\section{Brand preference value correlates and Schwart' theory}

Rokeach (1973: 14) contended that specific decision-making events activate only relevant parts of the value system. Surprisingly, there has been no effort to systematically investigate this contention about the nature of the value/preference relationship. The two major components of the 
Schwartz theory, interests served and motivational value types, suggest a potential organizing criteria for value activation and two related hypotheses:

Hypothesis 3a: Significant brand preference value correlates will serve either individual, collective or mixed interests.

Hypothesis 3b: Significant brand preference value correlates will be of only one motivational type.

Inconsistent patterns emerge regarding motivational domains and interest contains values related to bank brand preference: security (inner harmony, national security and salvation), achievement (an exciting life and equality) and maturity (self-control).

An entirely different pautern emerges for building societies. There are no significant relationships between values serving collective interests and building society preference. Four motivational domains contain values related significantly to preference: enjoyment (pleasure), achievement (equality), self-direction (a sense of accomplishment and logical) and maturity (wisdom).

\section{A segmentation technique based on values and traditional segmentation criteria}

Establishing the correlation of relative value importance and financial services brand preference indicates neither the strength of the relationship in comparison to traditional segmentation techniques nor a method for operationalizing the relationship in marketing strategy. Two seminal contributors to the consumer research literature recently pointed out the need for consumer research to return to answering these kinds of questions (Sheth, 1992; Wells, 1993). Although a wide range of individual characteristics have been shown to influence consumer behaviour (see Engel, Blackwell \& Miniard, 1993), discussions with industry sources indicated that race, household income, education and age were the most popular segmentation criteria for banks and building societies. Thus, the current research tests these four categorical variables and the value rankings for each respondent using Classification and Regression Trees (CART) (Brieman, Friedman, Olshen \& Stone, 1984).

CART is a nonparametric alternative to automatic interaction detection and logistic analysis. CART analyzes rotating $10 \%$ partitions of the subsample produced at each node to identify the difference in one independent variable that maximally-discriminates between different levels of the dependent variable until a decision rule satisfies all subsamples. This obviously results in conservative decision rules. When the analysis overtaxes computer resources, as it did with banks in the current research, the computer enters exploratory mode and reduces the amount of crossvalidation. The quality of the CART segments was tested by constructing CART segment by brand preference contingency tables and testing for independence using $X^{2}$. The results suggest the CART segments for both product categories are related to brand choice $(p<.00001)$.

The analysis produces useful segments at each node but the terminal segments are most interesting. Shown in Figures 1 and 2 are the bank and building society market segments produced by the CART analysis. The decision

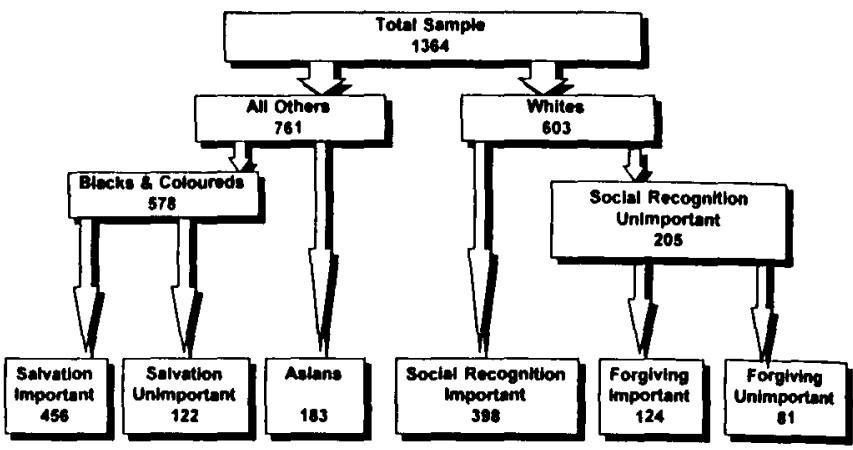

Flgure 1 Bank market segments CART binary decision tree: number of respondents at each node

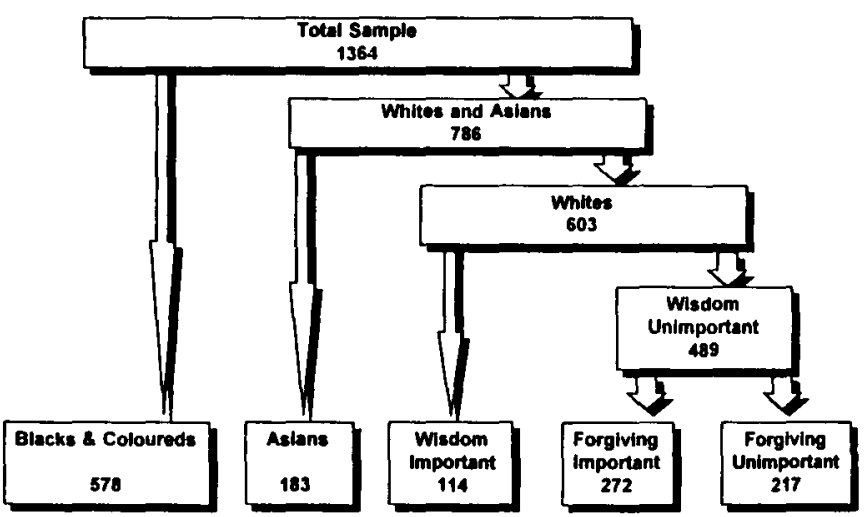

Figure 2 Building society market segments CART binary decision tree: number of respondents at each node

trees suggest race and values have a stronger association with brand preference than age, education or household income in both financial service categories.

Race is the most strongly associated with bank preference differences. CART partitioned the two primary racial segments. Blacks and Coloureds and Asians flow out of the All other segments. The importance of salvation partitions the Blacks and Coloureds segment. The White segment is subdivided into groups based on the relative importance of social recognition. The relative importance of forgiving further partitions Whites to whom social recognition is relatively unimportant. Thus, CART suggests six segments differentiated primarily by race and then by relative value importance.

Blacks and Coloureds and Asians emerge as two of the five building society segments. The Whites segment subdivides further based on the relative importance of wisdom and forgiving.

\section{Limitations}

The lack of translation into the more than 20 vernacular languages is a limiting factor. Although one study indicates that as many as $26.9 \%$ of Black South Africans living in urban areas could not speak English or Afrikaans, a larger majority probably speak English in the major metropolitan areas that are the focus of this study (Main Committee: HSRC, 1985). The administrators conduct extensive crosscultural research in South Africa and have won numerous 
Southem African Marketing Research Association awards for research standards. They estimate a maximum of $2 \%$ of Black respondents may have had difficulty with the instrument.

The assumption of respondent familiarity with banks and building societies may be another limiting factor. ABSA research during the time indicated that only $42 \%$ of Blacks operated savings accounts while less than $1 \%$ operated a cheque account. Of those who operated a savings account, $60 \%$ did so at a building society. However, financial services were among the most heavily advertised products and much promotional activity was directed at Black consumers. Fieldwork was conducted after a period of sustained above average industry promotional activity.

\section{Conclusions and suggestions for future research}

These findings suggest the RVS is sensitive to value differences related to preference for South African financial service brands. The findings regarding the relative importance of value differences in segmentation are important. No doubt many industry participants could present persuasive intuitive arguments suggesting age, household income and education should be primary segmentation criteria. Others might suggest that racial differences should no longer be important in a new South Africa. These results suggest otherwise. Financial services marketers would be wise to include race and values in their market segmentation research and brand positioning strategies. Race may be a summary construct for other differences and prudent marketers will constantly research its importance. The results also suggest that individual values, not value systems, should be the focus of interest regarding brand preference in these two categories.

The findings regarding relative value importance and brand choice are not surprising. Similar findings have been reported around the world and the tool seems to have reasonable validity. However, the inconsistent pattems regarding the interests served and motivational domains of the values linked to preference is puzzling and requires further research. The pattern of significant value relationships to bank preference suggests values from a narrow range of motivational domains serving all interests form the basis of value linkage to brand preference. The building society analysis suggests a wide range of motivational domains serving a limited number of interests form the basis of the relationship. Perhaps these patterns simply emerged here by chance. Alternatively, they may reflect a deeper relationship that will emerge with future research.

\section{Suggested future research}

These findings suggest a number of important issues that require future South African research.

International and Local Value Scales: Auempts should be made to test the appropriateness of comprehensive intemational scales, such as the Schwartz Value Survey (Schwartz, 1992), for South African consumer research. At the same time, attempts to develop original local values scales should be encouraged. Chinese attempts to measure values from an entirely Chinese perspective could serve as an example in this regard (Bond, 1991; Chinese Culture Connection, 1987).

Antecedents of value activation: Involvement, elaboration and emotion have become important recurring themes in diverse consumer research areas. The role these constructs play as activators of values could have important implications for promotional strategy and needs to be better understood.

Value systems, values and consequences: Future research should continue to define which of these constructs is the most appropriate for consumer research. Many more forms of behaviour should become frames of interest, such as attitude formation, preference for product features and benefits, problem-solving behaviour, involvement and the role of values in decision-making. There is also an urgent need for more knowledge about value activation in consumer choice processes. South African researchers are ideally placed to explore the influence of literacy and numeracy limitations on value activation.

Methodological advances: Schwartz' use of SSA lead to considerable advancement. Consumer research needs similar innovation. Kamakura \& Mazzon's (1991) recent use of logistic analysis is an example of the kind of progress needed.

A superior understanding of values could form the basis of significant sustainable competitive advantage for South African marketers. South Africa's dramatic cultural and economic diversity suggest local researchers might be ideally placed to lead development of globalized value research tools for consumer research. Thus, an exciting opportunity exists for increased academic and applied values research in South Africa. No doubt the results of such projects will receive great interest from academic and applied researchers throughout the world.

\section{Acknowledgements}

We wish to thank Michael Greenacre of the University of South Africa for the CART analysis and helpful comments. Hardie van Tiddens of the Amalgamated Banks of South Africa Ltd. Research Department, Neil Higgs of Research Surveys (Pty) Ltd. and Tim Bester and Sue Lerena of The McCann Group SA Ltd. provided kind assistance.

\section{References}

Beatty, S.E., Kahle, L.R., Homer, P. \& Misra, S. 1985. 'Alternative measurement approaches to consumer values: The List of Values and the Rokeach Value Survey', Psychology and Marketing, Vol. 2, No. 3: 181-200.

Berglund, A.I. 1989. Zulu thought-palterns and symbolism. London: Hurst.

Berry, J.W. 1969. 'On cross-cultural comparability', International Journal of Psychology, Vol. 4: 119-128.

Bird. K.D. 1985. 'Simultaneous contrast testing procedures for multiv ariate experiments', Mulivariate Behavioural Research, July, 343-351.

Bond, M.H. 1991. 'Chinese values and health: A cultural-level examination', Psychology and Health, Vol. 5: 137-152.

Braithwaite, V.A. \& Law, H.G. 1985. 'Structure of human values: Testing the adequacy of the Rokeach Value Survey'. Journal of Personality and Social Psychology, Vol. 49, No. 1: 250-263. 
Brieman, L., Friedman, J., Olshen, R. \& Stone, C. 1984. Classification and regression trees. Belmont, California: Wadsworth.

Brislin, R.W., Lonner, W J. \& Thorndike, R.M. 1973. Crossculiural research methods. New York: Wiley.

Brith S.H. (ed.). 1966. Consumer behavior and the behavioral sciences. New York: Wiley.

Burgess, S.M. 1992. 'Personal values and consumer research: An historical perspective'. Research in Marketing, Vol. 11: 35-79.

Burgess, S.M., Schwartz, S. H. \& Blackwell, R.D. 1993. Do values share universal content and structure? A South African test. Business Economics Research Group Working Paper Series 93, Johannesburg: University of the Witwatersrand.

Burnett, T.D. \& Barr, D.R. 1977. 'A nonparametric analogy of analysis of covariance', Educational and Psychological Measurement, Vol. 37: 341-348.

Business Week. 1991. The 'bloodbath' in market research. 11 February 1991. Reprinted in McCarthy, E.J. \& Perreaulth W.D. Jr. (eds.). Applications in basic marketing: Clippings from the populary business press. 1992/3 edition. Homewood, Illinois: Irwin, pp.54-55.

Chinese Culture Connection. 1987. 'Chinese values and the search for culture-free dimensions of culture', Journal of Cross-Cultural Psychology, Vol. 18, No. 2: 143-164.

Clawson C.J. \& Vinson, D.E. 1978. 'Human values: A historical and interdisciplinary analysis'. In Hunt, H.K. (ed.). Advances in consumer research. Ann Arbor, Michigan: Association for Consumer Research. pp.396-402.

Cohen, J.B. 1968. 'The role of personality in consumer behavior'. In Kassarjian, H.H. \& Roberston, T.S. (eds.). Perspectives in consumer behavior. Glenview, Illinois: Scott Foresman, pp.220-233.

Dicter, E. 1984. 'How values influence attitudes'. In Pitts, R.E. \& Woodside, A.G. (eds.). Personal values and consumer psychology. Lexington, Massachusetts: Lexington. pp.139-144.

Engel, J.F., Kollat, D.T. \& Blackwell, R.D. 1968. Consumer behavior. New York: Holt Rinehart Winston.

Engel, J.F., Blackwell, R.D. \& Miniard, P.W. 1993. Consumer behavior. Seventh Edition. New York: Dryden.

Feather, N.T. 1973. 'The measurement of values: Effects of different assessment procedures', Australian Journal of Psychology, Vol. 25, No. 3: 221-231

Feather, N.T. 1984. 'Masculinity, femininity, psychological androgyny and the structure of values', Journal of Personality and Social Psychology, Vol. 47: 604-620.

Feather, N.T. \& Peay, E.R. 1975. 'The structure of terminal and instrumental values: Dimensions and clusters', Australian Journal of Psychology, Vol. 27: 157-164.

Feir-Walsh, B.J. \& Toothacker, L.E. 1974. 'An empirical comparison of the ANOVA F-test, normal scores test and Kruskal-Wallis test under violations of assumptions', Educational and Psychological Measurement, Vol. 34: 789-799.

Fisher, L. \& McDonald, J. 1978. Fixed effects: Analysis of variance. New York: Academic Press.

Gaito, J. 1978. 'Multiple comparisons within ANOVA using orthogonal or nonorthogonal components', Educational and Psychological Measurement, Vol. 38: 901-904.

Gutman, J. 1982. 'A means-end chain model based on consumer categorization processes', Journal of Marketing, Vol. 46, Spring: $60-72$.

Guttman, L. 1968. 'A general nonmetric technique for finding the smallest coordinate space for a configuration of points', Psychometrica, Vol. 33: 469-506.
Guttman, L. 1977. 'What is not what in statistics', The Statistician, Vol. 26: 81-107.

Gutuman, L. 1982. 'Facet theory, smallest space analysis and factor analysis', Perceptual and Motor Skills, Vol. 54: $491-493$.

Hammond-Tooke, W.D. 1989. Ritwals and medicine. Johannesburg: Donker.

Hofmeyer, B.E. \& Mostert, W.P. 1989. Demographic ageing of the South African population: Past (1945-1985) and expected trends (1985-2035). Pretoria: Human Sciences Research Council.

Howard, J.A. 1977. Consumer behavior: Application of theory. New York: MoGraw-Hill.

Integrated Marketing Research. 1991. Paneldala. Main report. Johannesburg: Integrated Marketing Research.

Journal of Advertising Research. 1988. Special values issue, February/March.

Journal of Business Research. 1990 Special issue on social values, Vol. 20, No.2, March.

Kahle, L.R. (ed.). 1983. Social values and social change: Adaptation to life in America. New York: Praeger.

Kahle, L.R., Beatty, S.E. \& Homer, P.M. 1986. 'Alternative measurement approaches to consumer values: The List of Values and Values and Lifestyle (VALS)', Journal of Consumer Research, Vol. 13: 405-409.

Kamakura, W.A. \& Mazzon, J.A. 1991. 'Value segmentation: A model for the measurement of values and value systems', Journal of Consumer Research, Vol. 18, September: 208-218.

Kassarjian, H.H. 1965. 'Social character and differential preference for mass communication', Journal of Marketing Research, Vol. 22: 146-153.

Kassarjian, H.H. 1971. 'Personality and consumer behavior: A review', Journal of Marketing Research, Vol.8, November: 409-418.

Kassarjian, H.H. \& Sheffet, M.J. 1991. 'Personality and consumer behavior: An update'. In Kassarjian, H.H. \& Robertson, T.S. Perspectives in consumer behavior. Fourth edition. Englewood Cliffs, New Jersey: Prentice-Hall, pp.281-303.

Keppel, G. 1982. Design and analysis: A researcher's handbook. Second edition. Englewood Cliffs, New Jersey: Prentice-Hall.

LaTour, S.A. \& Miniard, P.W. 1981. 'The use and misuse of repeated measures analysis in marketing research', Journal of Marketing Research, 20 February: 45-57.

Lessig. V.P. 1975. 'A measurement of dependencies between values and other levels of the consumer belief system', Jowrnal of Business Research. Vol. 3, No. 3, July: 227-240.

Lingoes, J.C. 1977. Geometric representations of relational dala. Ann Arbor: Mathesis.

Main Committee: HSRC. 1985. The South African society: Realities and future prospects. Pretoria: Human Sciences Research Council.

Mostert, W.P. \& Lstter, J.M. 1991. South Africa's demographic future. Pretoria: Human Sciences Research Council.

Munson, J.M. \& McIntyre, S.H. 1979. 'Developing practical procedures for the measurement of personal values in crosscultural marketing', Journal of Marketing Research, Vol. 16: 48-52.

Munson, J.M. \& McQuarrie, E.F. 1988. 'Shortening the Rokeach Value Survey for use in consumer research', Advances in Consumer Research, Vol. 15: 381-386.

Ng. S.H. 11982. 'Choosing between ranking and rating procedures for comparison of values across cultures', European Journal of Social Psychology, Vol. 12, 169-172. 
Novak, T.P. \& MacEvoy, B. 1990. 'On comparing alternative segmentation schemes: List of Values and Values and Lifestyles (VALS)', Journal of Consumer Research, Vol. 17, June: 105-109.

Psychology and Marketing. 1985. Psychology, marketing, and values: A special issue. Vol. 2, No. 4, Winter.

Rankin, W.L. \& Grube, J.W. 1980. 'A comparison of ranking and rating procedures for value system measurement', European Journal of Social Psychology, Vol. 10, No. 10: 233-246.

Reynolds, T J. \& Jolly, J.P. 1980. 'Measuring personal values: An evaluation of altemative methods', Journal of Marketing Research, Vol. 17, November: 531-536.

Rodger, R.S. 1973. 'Confidence intervals for multiple comparisons and the misuse of the Bonferroni inequality', British Journal of Mathematical and Statistical Psychology, Vol. 26: 58-60.

Rokeach, M.J. 1968. Beliefs, attitudes and values. San Francisco: Jossey-Bass.

Rokeach, M.J. 1973. The nature of human values. New York: Free Press.

Rokeach, M.J. 1979. Understanding human values. New York: Free Press.

Rosenberg, MJ. 1956. 'Cognitive structure and attitudinal affect', Journal of Abnormal and Social Psychology. Vol. 53, November: $367-372$.

Schwartz, S.H. 1992. 'Universals in the content and structure of values: Theoretical advances and empirical tests in 20 countries. In Zanna, M. (ed.). Advances in experimental social psychology, Vol. 25, (in press).
Schwartz, S.H. \& Bilsky, W. 1987. 'Toward a universal psychological structure of human values', Journal of Personality and Social Psyhology. Vol. 53, No. 3: 550-562.

Schwartz, S H. \& Bilsky, W. 1990. 'Toward a theory of the universal content and structure of values: Extensions and crosscultural replications', Journal of Personality and Social Psychology, Vol. 58, No. 5: 878-891.

Sheth, J.N. 'Acrimony in the ivory tower: A retrospective on consumer research', Journal of the Academy of Marketing Science. Vol. 20, No. 4: 345-354.

Sheth, J.N., Newman, B.I. \& Gross, B.L. 1991. Why we buy what we buy: A theory of consumption values. Cincinnati, Ohio: Southwestern.

Siegel, S. \& Castellan, NJ. 1988. Nonparametric statistics for the behavioral scinces. Second edition. New York: MoGrawHill.

Sinclair, R. 1985. Make the other half work too. Johannesburg: MacMillan.

South African Advertising Research Foundation. 1989. The allmedia and product survey AMPS 87/8. Johannesburg: South African Advertising Research Foundation.

Triandis, H.C. 1971. The analysis of subjective culture. New York: John Wiley.

Vinson, D.E., Scott, J.E. \& Lamont, L.M. 1977. 'The role of personal values in marketing and consumer behavior', Jowrnal of Marketing, Vol. 41, April: 44-50.

Wells, W.D. 1993. 'Discovery-oriented consumer research', Jownal of Consumer Research, Vol. 19, March: 489-504. 